\title{
Improved survival following surgery and radiation therapy for olfactory neuroblastoma: analysis of the SEER database
}

\author{
Mary E Platek ${ }^{1 *}$, Mihai Merzianu ${ }^{2}$, Terry L Mashtare ${ }^{3}$, Saurin R Popat ${ }^{4}$, Nestor R Rigual ${ }^{4}$, Graham W Warren ${ }^{5}$ and \\ Anurag K Singh ${ }^{5}$
}

\begin{abstract}
Background: Olfactory Neuroblastoma is a rare malignant tumor of the olfactory tract. Reports in the literature comparing treatment modalities for this tumor are limited.

Methods: The SEER database (1973-2006) was queried by diagnosis code to identify patients with Olfactory Neuroblastoma. Kaplan-Meier was used to estimate survival distributions based on treatment modality. Differences in survival distributions were determined by the log-rank test. A Cox multiple regression analysis was then performed using treatment, race, SEER historic stage, sex, age at diagnosis, year at diagnosis and SEER geographic registry.

Results: A total of 511 Olfactory Neuroblastoma cases were reported. Five year overall survival, stratified by treatment modality was: $73 \%$ for surgery with radiotherapy, 68\% for surgery only, 35\% for radiotherapy only, and $26 \%$ for neither surgery nor radiotherapy. There was a significant difference in overall survival between the four treatment groups $(p<0.01)$. At ten years, overall survival stratified by treatment modality and stage, there was no significant improvement in survival with the addition of radiation to surgery.
\end{abstract}

Conclusions: Best survival results were obtained for surgery with radiotherapy.

\section{Background}

Olfactory neuroblastoma (ONB) or esthesioneuroblastoma is an uncommon neuroendocrine malignancy which was first described by Berger et al. in 1924. [1]. ONB accounts for approximately $3 \%$ of endonasal neoplasms [2]. Though the etiology is unknown[2], ONB appears to arise from the olfactory membrane of the sinonasal tract and preferentially involves the anatomic distribution of the epithelium overlying the cribriform plate[2], superior turbinate and the superior nasal septum [3]. Patients most commonly present with nonspecific symptoms of nasal obstruction and epistaxis [2]. Less common symptoms include headache, pain, visual disturbances and anosmia [2]. ONB affects both sexes equally with a bimodal age distribution (the $2^{\text {nd }}$ and $6^{\text {th }}$

\footnotetext{
* Correspondence: mary.platek@roswellpark.org

'Division of Cancer Prevention and Population Sciences, Roswell Park Cancer Institute, Buffalo, New York, USA

Full list of author information is available at the end of the article
}

decades of life) although patients of all ages can be affected [2].

The rarity of ONB has limited study to individual case reports [4-8], small series [9-15], meta-analysis of such small series[16], or registry reports [17] and precluded prospective trials. Based on such limited data, the gold standard of care for these tumors is craniofacial resection followed by adjuvant radiotherapy $[10,18,19]$.

The Surveillance, Epidemiology, and End Results (SEER) database, which collects cancer incidence and survival data from cancer registries that are populationbased and cover approximately $26 \%$ of the United States population [20], was used to identify a large series of patients with ONB. In a prior report of the SEER database, Jethanamest et al. were unable to show a significant improvement in overall survival with the addition of radiation to surgery [17]. The objective of this study was to re-assess survival outcomes between different treatment modalities among the ONB cases identified
C Biomed Central

(ㄷ) 2011 Platek et al; licensee BioMed Central Ltd. This is an Open Access article distributed under the terms of the Creative Commons Attribution License (http://creativecommons.org/licenses/by/2.0), which permits unrestricted use, distribution, and reproduction in any medium, provided the original work is properly cited. 
from the SEER database with an additional four years of data.

\section{Methods Identification of Cases}

The SEER database for the years 1973 to 2006 was used to examine management strategies for ONB. The diagnosis code of $9522 / 3$ was queried and all records were found in the following sties: C30.0 (nasal cavity), C31.0 (maxillary sinus), C31.1 (ethmoid sinus), C31.2 (frontal sinus), C31.3 (sphenoid sinus), C31.8 (overlapping lesion of accessory sinuses) and C31.9 (accessory sinus, NOS). Information for the following treatment groups was queried: both surgery and radiotherapy, surgery only, radiotherapy only, neither surgery nor radiotherapy. Staging in the SEER data is based on classification criteria that vary by site and year of diagnosis. The SEER historic staging variable provided information for the following categories: localized, regional, distant and unstaged. Information for type, timing, and duration of chemotherapy was not available from the SEER database. The neuroepithelioma code, 9523/3, was also queried but there were no cases identified using this code.

\section{Statistical Analysis}

Treatment group information was summarized using frequencies and cumulative frequencies. The Kaplan-Meier method was used to estimate overall survival distributions by treatment modality. A Cox multiple regression analysis was performed using treatment, race, SEER historic stage, sex, age at diagnosis, year at diagnosis and SEER geographic registry. Overall survival was then estimated by stage comparing surgery only versus surgery with radiotherapy for local stage, regional stage and for local plus regional. These analyses were truncated for anyone with overall survival greater than 10 years. Statistical assessment of observed differences in survival distributions was done using the log-rank test in conjunction with a Bonferroni adjustment for multiple comparisons. A 0.05 nominal significance level was used in all hypothesis testing. Data analyses were performed using SAS, version 9.1.3, statistical software (SAS Institute., Cary, NC).

\section{Results}

A total of 511 cases of ONB were reported for the years 1973 to 2006. A description of this cohort can be found in Table 1. There was a unimodal distribution of ages with most cases between the ages of 40 and 70 years old (mean age was 53 years, SD of 18). The majority of cases were treated with both surgery and radiotherapy (61\%), were white with $55 \%$ male and a primary tumor site in the nasal cavity. Information concerning whether radiation therapy was administered before or after surgery was not available. Approximately $22 \%$ of the cases
Table 1 Description of SEER ONB cohort ( $N=511)$

\begin{tabular}{|c|c|c|}
\hline Characteristic & Frequency & Percent \\
\hline \multicolumn{3}{|l|}{ Age (years) } \\
\hline \multicolumn{3}{|l|}{$(n=485)$} \\
\hline$<25$ & 38 & 8 \\
\hline $25-39$ & 59 & 12 \\
\hline $40-69$ & 299 & 62 \\
\hline$>70$ & 89 & 18 \\
\hline \multicolumn{3}{|l|}{ Gender } \\
\hline Male & 283 & 55 \\
\hline Female & 228 & 45 \\
\hline \multicolumn{3}{|l|}{ Race } \\
\hline White & 415 & 81 \\
\hline Black & 41 & 8 \\
\hline Other & 51 & 10 \\
\hline Unknown & 4 & 1 \\
\hline \multicolumn{3}{|l|}{ Primary Tumor Site } \\
\hline Nasal Cavity & 370 & 72 \\
\hline Maxillary sinus & 22 & 4 \\
\hline Ethmoid Sinus & 65 & 13 \\
\hline $\begin{array}{l}\text { OthSinus (frontal, sphenoid accessory } \\
\text { sinuses) }\end{array}$ & 54 & 11 \\
\hline \multirow{2}{*}{\multicolumn{3}{|c|}{$\begin{array}{l}\text { SEER Historic Stage } \\
\qquad(\mathrm{n}=473)\end{array}$}} \\
\hline & & \\
\hline Localized & 112 & 24 \\
\hline Regional & 210 & 44 \\
\hline Distant & 129 & 27 \\
\hline Unstaged & 22 & 5 \\
\hline \multicolumn{3}{|l|}{$\begin{array}{c}\text { Treatment } \\
(\mathrm{n}=485)\end{array}$} \\
\hline Both Surgery and Radiation & 296 & 61 \\
\hline Surgery Only & 105 & 22 \\
\hline Radiation Only & 53 & 11 \\
\hline Neither Surgery Nor Radiation & 31 & 6 \\
\hline
\end{tabular}

received surgery only, $11 \%$ received radiation therapy alone and approximately $6 \%$ did not receive surgery or radiotherapy. The distribution of treatment methods and outcomes among the 511 cases is shown in Table 2. There was a statistically significant difference in the overall survival between these four treatment groups (surgery and radiotherapy, surgery only, radiotherapy only, and neither surgery nor radiotherapy) ( $<0.01$ ). The percentage of cases surviving five years by treatment modality was: $73 \%$ for surgery and radiotherapy, $68 \%$ for surgery only, $35 \%$ for radiotherapy only and $26 \%$ for neither radiotherapy nor surgery.

Pair-wise comparisons demonstrated a statistically significant difference in the overall survival distributions between four of the pairs. The overall survival distribution between patients who received both surgery and radiotherapy was significantly different from patients who received radiotherapy only $(p<0.01)$ and from 
Table 2 Distribution of Treatment Methods and Outcomes for SEER ONB

\begin{tabular}{ccccc}
\hline Treatment & $\begin{array}{c}\text { Total } \\
\mathbf{n}=\mathbf{4 8 5 ^ { * }} \\
\mathbf{N}(\mathbf{\%})\end{array}$ & Number Failed & Number Censored & Median Estimate (months) \\
\hline Both Surgery and Radiotherapy & $296(61.0)$ & 109 & 187 & 150 \\
\hline Surgery Only & $105(21.7)$ & 41 & 64 & 169 \\
\hline Radiotherapy Only & $53(10.9)$ & 30 & 13 & 39 \\
\hline Neither Surgery nor Radiotherapy & $31(6.4)$ & 18 & 10 \\
\hline
\end{tabular}

*26 cases with either surgery and/or radiotherapy information missing

patients who received neither surgery nor radiotherapy $(\mathrm{p}<0.01)$. Additionally, the overall survival distribution between patients who received surgery only was significantly different from patients who received neither surgery nor radiotherapy $(p=0.03)$ and from patients who received radiotherapy only $(p=0.046)$ All other comparisons were not significantly different. Figure 1 shows overall survival curves stratified by treatment groups.

Cox multiple regression analysis was performed to adjust for interaction between covariates and confirmed that treatment remained a significant predictor of overall survival $(\mathrm{p}<0.01)$. However, the overall survival distribution between patients who received surgery only was no longer significantly different from patients who received radiotherapy only $(\mathrm{p}=0.13)$.

Estimated ten year overall survival comparing surgery only versus surgery with radiotherapy stratified by local stage, regional stage and local plus regional stage showed no difference between these treatment methods for any stage.

\section{Discussion}

This analysis of the SEER database represents the largest published series of ONB cases. Five year overall survival

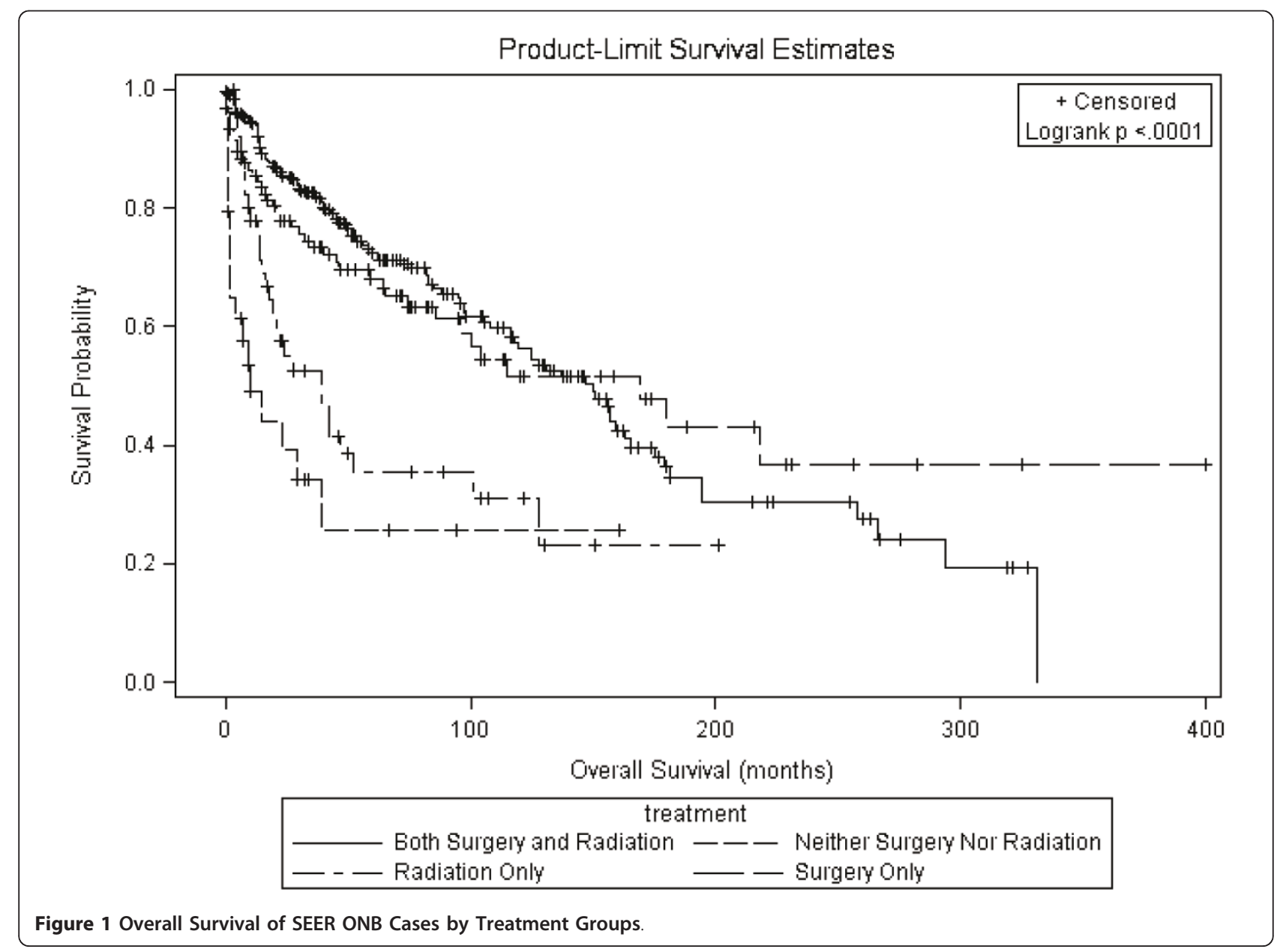


stratified by treatment was: $73 \%$ for surgery and radiotherapy, $68 \%$ for surgery only, $35 \%$ for radiotherapy only, and $26 \%$ for neither surgery nor radiotherapy. There was a significant difference in overall survival between the four treatment groups $(\mathrm{p}<0.01)$. There was a significant difference in five year overall survival distributions between patients receiving surgery and radiotherapy and patients receiving radiotherapy only $(\mathrm{p}<0.01)$.

Of note, only 31 patients received "neither surgery nor radiotherapy." Based on historic staging information from the SEER database, $84 \%$ of these patients had regional or distant disease. The lack of a significant survival benefit compared with surgery alone or surgery with radiotherapy is likely an artifact of these small numbers.

Based on five year survival stratified by treatment and consistent with one meta-analysis, smaller series and a previous examination of the SEER database, this analysis of SEER data shows that surgery with radiotherapy provides optimal management for ONB $[9,10,16,17]$. Jethanamest et al. analyzed the SEER database from 1973-2002, identified 311 eligible patients, and reported longest duration of mean survival was for cases receiving both surgery and radiotherapy but also reported that the only significant differences between treatment groups was for those receiving radiotherapy alone and those receiving combined modality treatment [17]. The authors also performed a detailed analysis in which they attempted to infer the patients' Kadish stage from the information available in the SEER database. Such an analysis, lacking any clinical or radiologic basis, has obvious limitations which were ably enumerated by the authors in their discussion. Due to these limitations, we did not make an effort to repeat inference of the Kadish stage.

Dulguerov et al. performed a meta-analysis of ONB publications between 1990 and 2000 (26 studies, 390 patients) with the objective to review recent developments in diagnosis, staging and treatment [16]. The optimal approach to treatment in this meta-analysis was a combination of surgery and radiotherapy. Gruber et al. and Lund et al. concluded the same (Table 3) $[9,10]$.

Radical surgery, however, of early stage lesions is not performed at all centers [4], and there are reports that endonasal endoscopic resection and postoperative adjuvant radiotherapy yields comparable outcomes to open craniofacial resection and adjuvant radiation therapy [18,21-23]. The advantage of sample size in this SEER analysis, while a distinct benefit in comparison to smaller single institution series, does come at the cost of limited documentation of treatment detail. For example, the SEER database did not include type of surgical resection.

In a recent meta-analysis of patient data for ONB between 1992 and 2008, endoscopic surgery was shown to be a valid treatment method to open surgery [24]. This SEER analysis is not able to discriminate any potential differences in outcomes with open craniofacial versus endoscopic resection. Additionally, the time period for the SEER database, 1973-2006, includes a time period before the beginning of the modern age of skull base surgery (1985-1990). A stratification of patient survival by year of diagnosis may facilitate understanding if current treatment paradigms are better than prior ones and particularly for surgical procedure, but the limited numbers even in this cohort would make any conclusions based on stratified analyses untenable. We did include year at diagnosis as a covariate in our Cox regression model.

\section{The Role of Chemotherapy}

The SEER database did not include information for those treated with chemotherapy, however recent reports of outcomes for ONB patients have included chemotherapy [11-15]. These findings are summarized in Table 3.

\section{Selection Bias: A Major Limitation of Any Retrospective Review}

Selection bias, which confounds any retrospective review, is particularly relevant in this analysis when comparing the surgery only and surgery plus radiation groups. This bias exists because clinicians treating the patients whose data is captured in the SEER database made decisions to give or omit radiation following surgery often based on clinical/pathologic/radiographic information that is not captured by SEER. Thus, one suspects that patients given surgery and radiation had poorer prognostic factors than those who received surgery alone. The absence of a statistically significant survival benefit with the addition of radiation must be interpreted within the context of this possible selection bias. In this analysis, we examined ten year survival by stage (local, regional and local plus regional) for surgery compared to surgery with radiotherapy and did not find a statistically significant difference for any stage.

\section{Other Limitations of the SEER Database: Pathologic, Terminology, Taxonomy, Grading and Staging Considerations}

ONB is a tumor restricted to the area of olfactory neuroepithelium, which arises from embryonic olfactory placodes and in adults is replaced partially by respiratory mucosa. Not surprisingly in a tumor arising from the neural-epithelial olfactory mucosa, the phenotype of ONB is intermediate between that of pure neural neoplasms (neuroblastoma and paraganglioma) and neuroendocrine epithelial tumors (carcinoid, neuroendocrine carcinoma, small cell carcinoma) [25]. This intrinsic 
Table 3 Summary of Published Single Institution Experiences

\begin{tabular}{|c|c|c|c|c|c|c|}
\hline Study & Year & Institution & Period & $\begin{array}{l}\text { No. of patients } \\
\text { ( } \mathrm{f} / \mathrm{u} \text { in months) }\end{array}$ & $\begin{array}{l}\text { Treatment } \\
\text { Received }\end{array}$ & Findings \\
\hline $\begin{array}{l}\text { Gruber et al. } \\
{[9]}\end{array}$ & 2002 & $\begin{array}{l}\text { Universities of Berne and } \\
\text { Zurich }\end{array}$ & $\begin{array}{l}1980- \\
2001\end{array}$ & $28(68)$ & $\begin{array}{l}\text { Group 1: S } \\
\text { (radical) + RT } \\
\text { Group 2: S(partial) } \\
+ \text { RT }\end{array}$ & $\begin{array}{l}10 \text { year DFS: } \\
\text { Group 1: } 55 \% \\
\text { Group 2: } 0 \%\end{array}$ \\
\hline $\begin{array}{l}\text { Lund et al. } \\
{[10]}\end{array}$ & 2003 & University College London & $\begin{array}{l}1978- \\
2001\end{array}$ & $45(57)$ & $\begin{array}{l}\text { Group 1: } S \text { alone } \\
\text { Group 2: } S+R T\end{array}$ & $\begin{array}{l}\text { Local Recurrence } \\
\text { Group 1: } 28 \% \\
\text { Group 2: } 8 \%\end{array}$ \\
\hline \multicolumn{7}{|c|}{ Studies Including Chemotherapy } \\
\hline $\begin{array}{l}\text { Rastogi et al. } \\
\text { [11] }\end{array}$ & 2006 & $\begin{array}{l}\text { King George Medical } \\
\text { University }\end{array}$ & $\begin{array}{l}1988- \\
2004\end{array}$ & $8(36)$ & $\begin{array}{l}\text { All Patients: } \\
S \text { (NCFR) }+ \text { RT }+C\end{array}$ & $\begin{array}{l}3 \text { year DFS/OS: } \\
72.9 \% / 71.4 \%\end{array}$ \\
\hline $\begin{array}{l}\text { Kim et al. } \\
{[12]}\end{array}$ & 2007 & $\begin{array}{l}\text { Four General Hospitals in } \\
\text { South Korea }\end{array}$ & $\begin{array}{l}1990- \\
2004\end{array}$ & $10(44.9)$ & $\begin{array}{l}\text { Group 1: S (+/- } \\
\text { RT) } \\
\text { Group 2: CCRT }\end{array}$ & $\begin{array}{l}5 \text { year DFS: } \\
\text { Group 1: } 68 \% \\
\text { Group 2: } 42 \%\end{array}$ \\
\hline $\begin{array}{l}\text { McLean et al. } \\
\text { [13] }\end{array}$ & 2007 & $\begin{array}{l}\text { Emory University-affiliated } \\
\text { hospitals }\end{array}$ & $\begin{array}{l}1991- \\
2006\end{array}$ & $21(47)$ & $\begin{array}{l}\text { Group 1: } S \\
\text { Group 2: } S+R T \\
\text { Group 3: } S+R T+C\end{array}$ & $\begin{array}{l}\text { Local Recurrence: } \\
\text { Group 1: } 0 \% \\
\text { Group 2: } 53.3 \% \\
\text { Group 3: } 43 \%\end{array}$ \\
\hline $\begin{array}{l}\text { Porter et al. } \\
{[14]}\end{array}$ & 2008 & Mayo Clinic Rochester & $\begin{array}{l}1976- \\
2003\end{array}$ & $12(\mathrm{~N} / \mathrm{A})$ & $\begin{array}{l}\text { Group 1: S (+/- } \\
\text { RT) } \\
\text { Group 2: S + C } \\
\text { (+/- RT) }\end{array}$ & $\begin{array}{l}\text { Median OS: } \\
\text { Group 1: } 78 \text { months } \\
\text { Group 2: } 83+\text { months }\end{array}$ \\
\hline $\begin{array}{l}\text { Bachar et al. } \\
{[15]}\end{array}$ & 2008 & Princess Margaret Hospital & $\begin{array}{l}1972- \\
2006\end{array}$ & $39(82.3)$ & $\begin{array}{l}\text { Group 1: S } \\
\text { Group 2: C } \\
\text { Group 3: RT } \\
\text { Group 4: } S+R T\end{array}$ & $\begin{array}{l}10 \text { year OS: } 69.2 \% \text { (all groups; OS pe } \\
\text { group N/A) } \\
\text { - S +RT optimal } \\
\text { - C did not influence outcome }\end{array}$ \\
\hline
\end{tabular}

Abbreviations: f/u (follow-up), S (surgery), RT (radiotherapy), DFS (disease free survival), NCFR (non-craniofacial resection), C (chemotherapy), OS (overall survival), CCRT (concurrent chemoradiotherapy), N/A (not available).

heterogeneity accounts for the various synonyms used to describe this neoplasm in the past: esthesioneuroblastoma, esthesioneuroepithelioma, (esthesio)neurocytoma, and even neuroendocrine carcinoma [26]. Due to its anatomic location, ONB is diagnosed in clinical practice by general surgical/head and neck pathologists and/or neuropathologists (depending on the surgical approach) who might use a slightly different terminology, as illustrated by the respective ONB description in the two corresponding WHO tumor classifications [2,25].

In addition, pathologic ONB definition has been refined in the period studied from being based exclusively on histomorphology [27-29] to include ultramicroscopic findings [26,29-33] and immunoprofile[2,25,32,34-36] in the diagnostic process. Regardless, it is worth noting that most ONB occurring in their characteristic location are easily recognizable, especially on the low grade side of the spectrum, which account for most cases reported in other series and (presumably) for the tumors reported to SEER database.

The only grading system available for ONB is unchanged from 1988 when Hyams proposed it based on the Armed Forces Institute of Pathology experience [37]. This system divides the ONB into four grades ranging from well (I) to least differentiated (IV) based on the tumor architecture, cellular pleomorphism, presence of neurofibrillary matrix and rosettes, mitotic activity, and presence of necrosis or calcifications. The grading system is somewhat subjective and sampling dependent (absent a complete resection) and its reproducibility is difficult to estimate due to the rarity of this disease.

The clinical staging introduced by Kadish a decade earlier describes mostly tumors of low Hyams grade [28]. A revised Kadish staging system which describes a stage D tumor as consisting of cervical or distant metastases was proposed by Morita [38]. In an analysis of survival and prognostic factors, Jethanamest et al. applied the modified Kadish staging system to 261 cases of esthesioneuroblastoma from the SEER database [17]. Cox regression analysis results showed that the staging system was a significant predictor of disease specific survival [17]. Other staging systems, based on the TNM staging system, have been proposed by Biller and Dulguerov $[39,40]$.

Without the benefit of a centralized pathology review we cannot stratify this SEER case series based on tumor grade; however the existing published experience and the above diagnostic considerations would support a bias toward low grade ONB reported to the SEER database $[28,40]$ although in some studies low and high grade tumors were evenly distributed without affecting the outcome [15]. 


\section{Conclusions}

This analysis of the largest series of ONB cases from the SEER database suggests, after accounting for selection bias, that best outcomes follow surgery combined with radiotherapy. The efficacy, timing, and optimum method of integrating chemotherapy with surgery and radiotherapy remain unknown.

\section{Acknowledgements}

This work was funded in part by the National Institutes of Health grant number R25CA114101

\section{Author details \\ 'Division of Cancer Prevention and Population Sciences, Roswell Park Cancer Institute, Buffalo, New York, USA. ²Department of Pathology, Roswell Park Cancer Institute, Buffalo, New York, USA. ${ }^{3}$ Department of Biostatistics, Roswell Park Cancer Institute, Buffalo, New York, USA. ${ }^{4}$ Department of Head and Neck/Plastic Surgery, Roswell Park Cancer Institute, Buffalo, New York, USA. ${ }^{5}$ Department of Radiation Medicine, Roswell Park Cancer Institute, Buffalo, New York, USA.}

\section{Authors' contributions}

MEP and TLM reviewed the SEER database for OFN cases and performed the statistical analysis. MEP, TLM, MM, and AKS wrote the manuscript. All authors reviewed the statistical analysis results, contributed to the interpretation of the results and read and approved the final manuscript.

\section{Competing interests}

The authors declare that they have no competing interests.

Received: 29 November 2010 Accepted: 25 April 2011

Published: 25 April 2011

\section{References}

1. Berger L, Luc G, Richard D: L'esthesioneuroepitheliome olfactif. Bull Assoc Franc Etude Cancer 1924, 13:410-412.

2. Wenig B, Dulguerov P, Kapadia S, Prasad M, Fanburg-Smith J, Thompson L: Neuroectodermal Tumours. In World Health Organization Classification of Tumours Pathology and Genetics of Head and Neck Tumours. Edited by: Barnes L, Eveson J, Reichart P, Sidransky D. Lyon: IARC Press; 2005:66-70.

3. lezzoni JC, Mills SE: "Undifferentiated" small round cell tumors of the sinonasal tract: differential diagnosis update. Am J Clin Pathol 2005, 124(Suppl):S110-121.

4. Ghaffar S, Salahuddin I: Olfactory neuroblastoma: a case report and review of the literature. Ear Nose Throat J 2005, 84(3):150-152.

5. Park MC, Weaver CE Jr, Donahue JE, Sampath P: Intracavitary chemotherapy (Gliadel) for recurrent esthesioneuroblastoma: case report and review of the literature. J Neurooncol 2006, 77(1):47-51.

6. Capelle L, Krawitz H: Esthesioneuroblastoma: a case report of diffuse subdural recurrence and review of recently published studies. J Med Imaging Radiat Oncol 2008, 52(1):85-90.

7. Chan LP, Wang LF, Tai CF, Wu CC, Kuo WR: Huge sphenoid sinus olfactory neuroblastoma: a case report. Kaohsiung J Med Sci 2009, 25(2):87-92.

8. McVey GP, Power DG, Aherne NJ, Gibbons D, Carney DN: Post irradiation olfactory neuroblastoma (esthesioneuroblastoma): a case report and up to date review. Acta Oncol 2009, 48(6):937-940.

9. Gruber G, Laedrach K, Baumert B, Caversaccio M, Raveh J, Greiner R: Esthesioneuroblastoma: Irradiation alone and surgery alone are not enough. Int J Radiation Oncology Biol Phys 2002, 54(2):486-491.

10. Lund VJ, Howard D, Wei W, Spittle M: Olfactory neuroblastoma: past, present, and future? Laryngoscope 2003, 113(3):502-507.

11. Rastogi M, Bhatt M, Chufal K, Srivastava M, Pant M, Srivastava K, Mehrotra S: Esthesioneuroblastoma treated with non-craniofacial resection surgery followed by combined chemotherapy and radiotherapy: An alternative approach in limited resources. Jpn J Clin Oncol 2006, 36(10):613-619.

12. Kim HJ, Kim CH, Lee BJ, Chung YS, Kim JK, Choi YS, Yoon JH: Surgical treatment versus concurrent chemoradiotherapy as an initial treatment modality in advanced olfactory neuroblastoma. Auris Nasus Larynx 2007, 34(4):493-498

13. McLean JN, Nunley SR, Klass C, Moore C, Muller S, Johnstone PA: Combined modality therapy of esthesioneuroblastoma. Otolaryngol Head Neck Surg 2007, 136(6):998-1002.

14. Porter AB, Bernold DM, Giannini C, Foote RL, Link MJ, Olsen KD, Moynihan TJ, Buckner JC: Retrospective review of adjuvant chemotherapy for esthesioneuroblastoma. J Neurooncol 2008, 90(2):201-204.

15. Bachar G, Goldstein DP, Shah M, Tandon A, Ringash J, Pond G, Gullane PJ, Perez-Ordonez B, Gilbert RW, Brown DH, et al: Esthesioneuroblastoma: The Princess Margaret Hospital experience. Head Neck 2008, 30(12):1607-1614.

16. Dulguerov P, Allal AS, Calcaterra TC: Esthesioneuroblastoma: a metaanalysis and review. Lancet Oncol 2001, 2(11):683-690.

17. Jethanamest D, Morris LG, Sikora AG, Kutler DI: Esthesioneuroblastoma: a population-based analysis of survival and prognostic factors. Arch Otolaryngol Head Neck Surg 2007, 133(3):276-280.

18. Argiris A, Dutra J, Tseke P, Haines K: Esthesioneuroblastoma: the Northwestern University experience. Laryngoscope 2003, 113(1):155-160.

19. Simon JH, Zhen W, McCulloch TM, Hoffman HT, Paulino AC, Mayr NA, Buatti JM: Esthesioneuroblastoma: the University of lowa experience 1978-1998. Laryngoscope 2001, 111(3):488-493.

20. National Cancer Institute: Surveillance Research Program CSBS, Epidemiology, and End Results (SEER) Program Limited-Use Data (19732006), Release April 2008.

21. Casiano RR, Numa WA, Falquez AM: Endoscopic resection of esthesioneuroblastoma. Am J Rhinol 2001, 15(4):271-279.

22. Unger $F$, Walch C, Stammberger H, Papaefthymiou G, Haselsberger K, Pendl G: Olfactory neuroblastoma (esthesioneuroblastoma): report of six cases treated by a novel combination of endoscopic surgery and radiosurgery. Minim Invasive Neurosurg 2001, 44(2):79-84.

23. Walch C, Stammberger $H$, Anderhuber W, Unger F, Kole W, Feichtinger K: The minimally invasive approach to olfactory neuroblastoma: combined endoscopic and stereotactic treatment. Laryngoscope 2000, 110(4):635-640.

24. Devaiah AK, Andreoli MT: Treatment of esthesioneuroblastoma: a 16-year meta-analysis of 361 patients. Laryngoscope 2009, 119(7):1412-1416.

25. Finkelstein SD, Hirose T, VandenBerg SR: Olfactory neuroblastoma. In Pathology and genetics of tumours of the nervous system. Edited by: Kleihues P, Cavenee WK. Lyon: International Agency for Research on Cancer Press; 2000:150-152.

26. Silva EG, Butler JJ, Mackay B, Goepfert H: Neuroblastomas and neuroendocrine carcinomas of the nasal cavity: a proposed new classification. Cancer 1982, 50(11):2388-2405.

27. Hutter RV, Lewis JS, Foote FW Jr, Tollefsen HR: Esthesioneuroblastoma. A Clinical and Pathological Study. Am J Surg 1963, 106:748-753.

28. Kadish S, Goodman M, Wang CC: Olfactory neuroblastoma. A clinical analysis of 17 cases. Cancer 1976, 37(3):1571-1576.

29. Batsakis JG: Tumors of the head and neck: clinical and pathological considerations. Baltimore: Williams \& Wilkins; 1979.

30. Kahn LB: Esthesioneuroblastoma: a light and electron microscopic study. Hum Pathol 1974, 5(3):364-371.

31. Curtis JL, Rubinstein LJ: Pigmented olfactory neuroblastoma: a new example of melanotic neuroepithelial neoplasm. Cancer 1982, 49(10):2136-2143.

32. Taxy JB, Bharani NK, Mills SE, Frierson HF Jr, Gould VE: The spectrum of olfactory neural tumors. A light-microscopic immunohistochemical and ultrastructural analysis. Am J Surg Pathol 1986, 10(10):687-695.

33. Hirose T, Scheithauer BW, Lopes MB, Gerber HA, Altermatt HJ, Harner SG, VandenBerg SR: Olfactory neuroblastoma. An immunohistochemical, ultrastructural, and flow cytometric study. Cancer 1995, 76(1):4-19.

34. Perez-Ordonez B, Caruana SM, Huvos AG, Shah JP: Small cell neuroendocrine carcinoma of the nasal cavity and paranasal sinuses. Hum Pathol 1998, 29(8):826-832.

35. Cohen ZR, Marmor E, Fuller GN, DeMonte F: Misdiagnosis of olfactory neuroblastoma. Neurosurg Focus 2002, 12(5):e3.

36. Sugita $Y$, Kusano K, Tokunaga $O$, Mineta $T$, Abe M, Harada $H$, Shigemori M: Olfactory neuroepithelioma: an immunohistochemical and ultrastructural study. Neuropathology 2006, 26(5):400-408.

37. Hyams VJ, Batsakis JG, Michaels L: Tumors of the Upper Respiratory Tract and Ear. Washington, DC: Armed Forces Institute of Pathology; 1988. 
38. Morita A, Ebersold MJ, Olsen KD, Foote RL, Lewis JE, Quast LM:

Esthesioneuroblastoma: prognosis and management. Neurosurgery 1993, 32(5):706-714, discussion 714-705

39. Biller HF, Lawson W, Sachdev VP, Som P: Esthesioneuroblastoma: surgical treatment without radiation. Laryngoscope 1990, 100(11):1199-1201.

40. Dulguerov P, Calcaterra T: Esthesioneuroblastoma: the UCLA experience 1970-1990. Laryngoscope 1992, 102(8):843-849.

doi:10.1186/1748-717X-6-41

Cite this article as: Platek et al:. Improved survival following surgery and radiation therapy for olfactory neuroblastoma: analysis of the SEER database. Radiation Oncology 2011 6:41.

Submit your next manuscript to BioMed Central and take full advantage of:

- Convenient online submission

- Thorough peer review

- No space constraints or color figure charges

- Immediate publication on acceptance

- Inclusion in PubMed, CAS, Scopus and Google Scholar

- Research which is freely available for redistribution

Submit your manuscript at www.biomedcentral.com/submit 